\title{
Precautions Prior to the Treatment in Oral and Maxillofacial Surgery in the Reopening Period during COVID-19 Pandemic
}

\section{COViD-19 Pandemisi Yeniden Açılma Döneminde Ağız Diş ve Çene Cerrahisinde Tedavi Öncesi Alınması Gereken Önlemler}

(D) Özge DOĞANAY, iD Doğan DOLANMAZ

Bezmialem Vakıf University Faculty of Dentistry, Department of Oral and Maxillofacial Surgery, İstanbul, Turkey

\section{ABSTRACT}

Oral and maxillofacial surgery is correlated with a high risk of severe acute respiratory syndrome-coronavirus-2 (SARSCoV-2) transmission. To assist our colleagues under physical and psychological burden by using the current literature data and considering the recommendations of the Ministry of Health Science board decisions, -The American Association of Oral and Maxillofacial Surgeons, American Dental Association and Centers for Disease Control and Prevention, this literature review has been prepared in order to organize elective surgeries. Interventions should be planned after evaluating both the logistic conditions of the institution and the situation during the pandemic before performing elective surgery. In order to save resources and to avoid unnecessary exposure to infected patients, there is the need to schedule interventions depending on their priority. In general, Emergency procedures do not allow any delay. In elective surgeries, risk assessments of both the patient and the surgical procedure is left to the surgeon. Inpatient and outpatient units have to be organized in such a way that the risk of cross-infection among patients is reduced to a minimum. Active Coronavirus disease-19 (COVID-19) patients should be treated in the operating room with negative pressure, and aerosol formation must be reduced to a minimum. During reopening period, treatments may be applied in cases where appropriate conditions are provided and recommendations for patient and physician safety are taken.

Keywords: COVID-19 pandemic, oral and maxillofacial surgery, personal protective equipment, reopening, elective treatments, protective measures
ÖZ

Ağız diş ve çene cerrahisi pratiği, şiddetli aku solunum yolu enfeksiyonu-2 (SARS-CoV-2) bulaştırıcılığı açısından yüksek riskli grupların arasında yer almaktadır. Sağlık Bakanlığı Bilim kurulu kararları, The American Association of Oral and Maxillofacial Surgeons, American Dental Association ve Centers for Disease Control and Prevention önerileri gözetilip, güncel literatür verileri kullanılarak, fiziksel ve psikolojik yük altındaki meslektaşlarımıza yardımcı olmak amacıyla elektif cerrahilerin planlanması ile ilgili bu literatür derlemesi hazırlanmıştır. Elektif cerrahiye geçmeden kurumun hem lojistik koşullarının, hem de pandemi içindeki durumunun değerlendirilmesinden sonra planlı cerrahinin/ girişimlerin programlanması yapılmalıdır. Kişisel koruyucu ekipman gibi kaynakları tasarruflu kullanmak ve enfekte hastalara olan gereksiz maruziyeti ortadan kaldırmak için tedavilerin öncelik sırasına göre planlanması gereklidir. Genel kanı olarak, Koronavirüs hastalığı (COVID-19) hastası acil cerrahi bir işlem için başvurduğunda gecikme yaşanmadan alınmaktadır. Elektif tedavilerde ise hastanın ve cerrahi işlemin risk durumu cerraha bırakılmaktadır. Servisler ve ayakta tedavi üniteleri, hastalar arasında çapraz enfeksiyon riskini en aza indirmek amacıyla yeniden düzenlenmelidir. Aktif COVİD-19 hastaları negatif basınçlı odalarda tedaviye alınmalı ve aerosolizasyon en aza indirilmelidir. COVID-19 pandemisi "yeniden açılma" periyodunda, salgın nedeniyle tedavisi yarım kalan ya da müdahale edilmesi gereken olgular için, uygun koşullar sağlandığı ve hasta/hekim güvenliği için yapılan önerilerin dikkate alındığı durumlarda tedaviler yapılabilir.

Anahtar Sözcükler: COVİD-19 pandemisi, ağı diş ve çene cerrahisi, kişisel koruyucu ekipman, yeniden açılma, elektif tedaviler, koruyucu önlemler 


\section{Introduction}

Epidemic Coronavirus disease-19 (COVID-19) disease caused by the virus named severe acute respiratory syndrome-CoV-2 (SARS-Cov-2) spread worldwide in a very short time after emerging in Wuhan, Hubei, China in the last month of 2019. The disease was recognized as the "International Public Health Emergency" by the World Health Organization on January 30, 2020, and a global pandemic was declared on March 11, 2020. Turkey also has taken its place among the countries affected by the pandemic and described the first official event on March 11, 2020.

The Ministry of Health listed the measures to be taken to minimize the density in health institutions and to reduce the burden on health personnel with the circular number 14500235 403.99 dated 17/03/2020. Among these items, non-emergency elective surgical procedures; It was pointed out that under the extraordinary conditions caused by the pandemic, the efficient and rational use of health resources, planning a more appropriate date as possible in order to minimize the possibility of contamination between patients and strategically important healthcare professionals in this process.

On the other hand, sustainability of healthcare services and "necessary" initiatives other than COVID-19 has gained importance over the past 70 days. In this context, it has emerged that the patients who continue their active treatment and are interrupted due to the pandemic need to evaluate and plan the procedures to increase or protect the quality of life or function and pain treatments during the reopening process.

Representing the physician group who are active in the perioperative process, the decisions of the Ministry of Health Scientific Committee, The American Association of Oral and Maxillofacial Surgeons (AAOMS), American Dental Association (ADA) and Centers for Disease Control and Prevention (CDC) recommendations; using the current literature data, we review on the planning of elective surgeries has been prepared to help our colleagues under physical and psychological burden. Before implementing the directives in this review, regional factors should be considered first, and the decision should be made with the local health authority, taking into account the characteristics and possibilities of the institution in transition to elective operations.

Organization of the planned surgery/interventions should be done after evaluating both the logistic conditions of the institution and its situation in the pandemic before proceeding to elective surgery. Especially defining the concept of "elective surgery" very clearly and developing a common language among disciplines will be very useful in increasing harmony.

\section{Clinical Findings of COVID-19 Infection}

The incubation period of COVID-19 infection has been shown to be between 1-14 days, and asymptomatic individuals have been shown to play an important role in the spread of the virus. The possibility of transmission from asymptomatic carriers has increased today and therefore, measuring body temperature alone is not sufficient to screen these carriers (1-3).

In the prodromal phase, the primary symptoms of non-specific reported COVID-19 infection are malaise, fever, and dry cough. The most commonly reported signs and symptoms are fever (98\%), cough (76\%), shortness of breath (55\%), myalgia or weakness (44\%). Unlike other coronavirus infections (SARS$\mathrm{CoV})$, upper respiratory and intestinal symptoms such as sore throat, runny nose and diarrhea are less common in COVID-19 infection $(1,4,5)$.

\section{Case Selection during Pandemic Period}

In this period, in order to safely perform interventions related to oral and maxillofacial surgery, the principles of simplifying the surgery were adopted by avoiding very complex and long-lasting surgical approaches (6). In cases where it cannot be determined whether the patient has COVID-19 (+) or not, strict precautions should be taken prior to elective practices to protect healthcare workers. Conducting the intervention in demarcated areas will ensure effective use of limited resources. For this purpose, a classification has been proposed according to the need for treatment related to maxillofacial surgery applications in the pandemic period (Table 1) (7).

Although no classification or algorithm has been proposed for oral and maxillofacial surgery in the re-opening period, it is recommended to plan elective surgeries taking into account certain criteria (Table 2) (8).

\section{Things to Consider Before Elective Surgery}

Before starting planned surgeries, in addition to evaluating the institutional facilities, cooperation and coordination with the local health authority should be ensured, the situation of the region in the pandemic should be evaluated together, and a period of continuous decrease in the rate of new COVID-19 cases should be ensured for at least 14 days in the relevant region (8).

\section{Evaluation of COVID-19 Patients}

Based on the available information, it is recommended to consider surgery in COVID-19 (+) cases only if life-threatening is in question, due to the high morbidity and mortality rates in early surgery (9).

In elective cases with COVID-19 (+), it is recommended to postpone elective therapy until the infection has resolved, symptoms have resolved and the patient has acquired COVID-19 (-) Antigen (Ag) for 28 days. Patients who do not show signs of COVID-19 can be considered as COVID-19 (+), and elective surgeries can be planned by taking necessary precautions (7-11).

\section{COVID-19 Diagnostic Opportunities}

As a rapid test for diagnosis, real-time reverse transcription polymerase reaction (PCR) tests are currently preferred, despite the high false negativity rate (approximately 30\%) (12). 
Table 1. Recommendations regarding the implementation of surgical procedures during the COVID-19 pandemic (Accepted: 31/03/2020) (7).

Procedures

- Orbital decompression (visual acuity unaffected)

- Orthognathic surgery

- Primary and secondary surgery for cleft lip and palate malformations

- Secondary reconstructive procedures (free/pedicled flaps)

- Surgery for temporomandibular pathologies causing limited pain

- Treatment of craniofacial malformations without sleep apnea/high intracranial pressure

- Benign, slow-growing tumors

- Closed fractures with limited dysfunction

- Large cystic lesions

- Surgery for temporomandibular pathologies causing severe pain

- Sleep apnea/treatment of craniofacial malformations with high intracranial pressure

- Deep head and neck infections without risk of airway obstruction

- Malignant tumors with / without reconstructive procedures

- Orbital decompression (decreased visual acuity)

- Open, fragmented broken

- Tracheotomy (expected airway obstruction)

- Deep head and neck infections with risk of airway obstruction

- Serious bleeding

COVID-19: Coronavirus disease-19
Table 2. Patient characteristics expected to be taken in the first place in the reopening period (8)

Re-opening period: patient characteristics for elective surgery

- Emergencies and mandatory treatments

- Required but delayed cases

- Individuals without concomitant illnesses

- Short-term local operations

- Outpatient procedures that do not require hospitalization, if possible

- If general anesthesia is required, the estimated operation time is less than 3 hours

- ASA 1-2 cases under 65 years of age

- Does not require blood transfusion

- Short-term transactions in a single session, if possible

In line with the information obtained so far, it has been stated that antibody testing has no role in perioperative screening and risk stratification (13). Antibodies develop in the second week
Proposal

Postponing surgery until the COVID-19 pandemic period is resolved

Postponing surgery until the COVID-19 pandemic period is resolved

Postponing surgery until the COVID-19 pandemic period is resolved as long as the risks associated with procrastination are under control

Postponing surgery until the COVID-19 pandemic period is resolved as long as the risks associated with procrastination are under control; it must be confirmed that there is improvement!

Surgical

Surgical; It must be confirmed that there is improvement!

Surgical

Surgical 
be disinfected in accordance with the manufacturer's instructions $(9,17)$.

Removing all non-cleanable objects such as flowers, vases, boxes, bags, books, personal computers from the environment, simplifying the field, covering areas that cannot be cleaned with disinfectants such as keyboards, computers, reflectors with transparent films before each patient, and removing disposable films after each patient. The room should be cleaned in accordance with the disinfection protocols and covered with new films before each patient admission. After the patient leaves the room, depending on the size of the room, ventilation should be provided for at least 15 minutes, and the floor and surface of the room should be cleaned by wearing a mask, goggles and gloves. Areas with organic residues such as blood, saliva, and dental material should be wiped with water-soap/detergent before disinfection $(9,18)$.

In all procedures likely to contain aerosols, spill-based measures should be applied according to the ministry of health guidelines for all personnel who will be closer to 6 steps. It is recommended to apply and use advanced high volume evacuation methods to remove aerosols generated during operation. Although these methods are not $100 \%$ effective, they can limit the degree of contamination of the surgical environment. It is recommended that emergency treatment of patients known to have COVID-19 $(+)$ in dental faculty clinics should be performed in rooms with an appropriate ventilation system (negative pressure ventilation system) $(9,19)$.

\section{Personal Protective Equipment (PPE)}

Maxillofacial surgeons are exposed to a high risk of viral transmission due to constant exposure to saliva, sputum and other body fluids. Therefore, it is recommended to use a mask, goggles and gloves during surgery or clinical examination $(9,10)$.

Standard donning and doffing procedures for personal protective equipment (PPE) must be followed. Disposable shoe covers or special intraoperative shoes/slippers designed for in-clinic use only should be used, and civilian clothes should be replaced with surgical uniforms when entering and leaving the clinic. All personnel must wear a face mask at all times. In order for the patients to identify the treating team, it is recommended that the names of the team be affixed/written on the face protective visor or on the backs of the overalls. The order to wear protective equipment; Surgical overalls/gowns, surgical masks, goggles with closed sides, cap, face protective visor and gloves, and the order of removal should be in the form of gloves, protective visor, cap, goggles, apron and surgical mask. In addition to the use of proper PPE, frequent hand hygiene should always be practiced. PPE should be thrown into the medical waste bin after use, and hand hygiene should be applied before and after wearing PPE $(16,18)$.

Antiseptic mouthwashes are thought to reduce viral load in the oral cavity $(20,21)$. For this purpose, it is recommended to gargle with $1.5 \%$ hydrogen peroxide or $0.2 \%$ Betadine/povidone iodine for 60 seconds before the procedure. However, it should be noted that the iodine solution tastes bad, temporarily stains the mucosa and teeth, and may pose an increased risk of allergies. The use of peroxide products with a better taste can be considered for patient comfort and compliance (9).

\section{PPE for Non-aerosol Generating Procedures (8)}

- Eye protection; If not available, full face shields must be weared.

- High filtration or Type III (N99/FFP3) procedure mask.

- Re-washable or disposable surgical gown.

- Surgical gloves (double gloves may be considered to help limit contamination during doffing).

- If the procedure involves using an aerosol generating device unplanned, stop the procedure and go to the aerosol generator PPE protocol.

\section{PPE for Aerosol Generating Procedures (Drill with Irrigation,} Cautery, LASER, Ultrasonic Instrumentation, etc.) (9)

- The entire surgical team should follow the same level of PPE protocol.

- Face shield/visor

- OSHA Respiratory Protection Instructions, NIOSH or FDA certified, disposable N95 filter face mask or N99 face mask

- Surgical gloves (double gloves can be considered to help limit contamination during doffing)

- If possible, the use of smoke generating devices such as cautery should be limited, and rapid evacuation should be ensured by special intraoral and/or extraoral devices, High Volume Evacuation (HVE) and/or advanced aerosol evacuation methods.

- Reusable or disposable surgical gown

- Disposable or washable hair protection/surgical cap/bonnet.

\section{Planning of Elective Surgery}

In the case of COVID-19 infection, surgery is only recommended if vital. In the early period of the pandemic, it has been reported that the mortality in patients who were operated with insufficient evaluation increased up to $20-50 \%(22,23)$. Therefore, in cases where elective surgery is planned, the recommended approaches to minimize the risk of transmission are as follows $(7,9,10,18)$.

\section{Infection Control}

i. For the elective surgery candidate, COVID-19-specific symptom, suspicious contact in the last 14 days, etc. A checklist questioning the situations should be completed.

ii. Information should be obtained about the use of antipyretic drugs including ibuprofen, acetaminophen or aspirin in the last 14 days.

iii. Non-contact infrared temperature meters measured on the forehead should be preferred and the temperature should be confirmed to be lower than $38^{\circ} \mathrm{C}$. 
iv. Thoracic CT imaging is not recommended as a screening test in asymptomatic cases. In suspicious cases, in the presence of symptoms such as fever, cough, and respiratory distress, preoperative thoracic CT imaging is recommended for further evaluation.

v. PCR testing is recommended for patients in non-urgent procedures that are planned with general anesthesia (7). Depending on the institution's test capacity and rapid conclusion, it is recommended that every patient should have 2 studied or 1 negative PCR result in the last 24 hours. In the follow-up of the test, the patient should be isolated at home.

vi. In general anesthesia procedures, the patient must be awakened in the operating room where the procedure is performed. During the recovery period, the patient should be monitored by placing a face shield instead of a surgical mask.

vii. Anesthesiology and transport personnel should be subject to the same level of infection control as surgical personnel.

viii. The postoperative service or intensive care bed of the patient to be taken under general anesthesia should be determined according to the PCR result.

ix. Considering the false negative rate of the PCR test, all elective surgery patients should be evaluated as suspected COVID-19 patients and should wear a surgical mask, and the approach in the operating room should be based on the same result.

$x$. The cases with positive PCR test but without any clinical and radiological findings except anosmia, gastroentistinal system findings, and generalized muscle pain; it is recommended to undergo elective surgery at the earliest 28 days after 2 negative PCR tests. Current information indicates that the risk of transmission will disappear after this time.

xi. There is not enough information in the literature about the recovery process of patients who have had COVID pneumonia (with PCR positive, respiratory symptoms and tomography findings). In this group, individual factors (age, comorbid diseases, etc.), characteristics of the surgery and respiratory functions during the recovery period can be evaluated and elective surgery can be planned by taking the opinion of the chest diseases specialist.

xii. In the advanced age group who is at high risk for COVID-19, the surgical requirement should be reconsidered, and a selective approach should be adopted for the near term in elective cases $(7,9,18)$.

\section{Appointment System/Patient Screening}

In cases where an aerosolized procedure is to be performed, it is recommended that the number of people exposed to aerosols should be minimized and the day should be scheduled, and if possible, aerosolized procedures should be written for appointments at the last hours of the day.

Pre-appointment screening procedure should be applied to every patient. Using the patient follow-up form, symptoms associated with COVID-19 (fever, cough, shortness of breath, muscle-headthroat pain, weakness, flu-like symptoms, loss of taste-smell, history of contact with a person with or diagnosed COVID-19 symptoms, existence etc.) should be questioned.

For patients who are new to the health institution or who want to come for control, it is recommended to arrange the institutional facilities so that they can request an appointment by phone or using the web-appointment system. Patients should be contacted and their complaints related to dental treatments should be recorded and a record should be created for the priority order. The patient should stay in the clinic for as short a time as possible, and the necessary preparations should be completed beforehand. Patients in the high risk group for COVID-19 (over 65 and those with comorbid diseases) should not be written consecutively, and their appointments should be arranged as the first patient.

After the patients are pre-screened in the appointment system, an appointment should be made for the patients whose suspected COVID-19 (+) is excluded. In the meantime, it is important to provide preliminary information that they will be treated by screening again on the day of the procedure and signing an informed consent form if there is no doubt, in order to preserve the functionality of the new system.

Prior to the appointment, patients should be informed that if they show any symptoms that raise suspicion of possible COVID-19, they should reach out to the faculty or physician and request that their appointment be delayed. In this case, patients should be referred to the triage service for a detailed screening $(7,9)$.

\section{Precautions to be Taken in the Operating Room}

There should be a minimum number of people in the operating room. If possible, only a doctor and a physician assistant should be present at the bedside, and the demand for supplies should be met by a waiting staff. The physician or assistant in charge of the patient should not leave the room before the procedure is completed by taking supplies or for another reason. If an outside staff needs to enter the operating room, they must follow the same PPE protocol as the surgical team. The operating room door should be kept closed at all times, and if there is a window, it should be left open.

An experienced team should carry out the surgery as much as possible. If the extraoral approach will be an alternative to the intraoral approach, it may be preferred to the intraoral approach to reduce aerosol formation. Using the water cooling system for hand motors, saws, ultrasonic and piezoelectric devices at maximum flow rate should be avoided. Instead of creating screw holes with rotary tools, self-piercing screws and bone cutters such as osteotomes may be considered. The use of electrocautery should be avoided or, if possible, used at the lowest power and with a smoke evacuation system $(7,9)$.

\section{Informed Consent Form}

Although all necessary precautions have been taken with current information in patients undergoing elective surgery during the COVID-19 pandemic period, it is important to provide 
additional information about the risk of transmission and to have the patient / patient's relative sign an informed consent form $(9,10)$.

\section{Postoperative Period}

After the operation, the patient's epicrisis report should be recorded completely, including the entry-exit hours and the cleaning time of the operating room (9). There is controversy regarding the use of non-steroidal anti-inflammatory (NSAI) drugs such as ibuprofen in suspected and confirmed cases of COVID-19 when pharmacological management of pain is required. For pain control and antipyretic efficacy, it is recommended that paracetamol group drugs be the first choice, but the use of NSAI drugs should not be avoided when necessary $(24,25)$. It is also stated that penicillin and clindamycin derivative antibiotics can be used safely in patients with known or suspected COVID-19 (26).

When appropriate, it may be recommended to make postoperative controls by teleconference method. The use of absorbable sutures can be considered in order not to increase the clinical density with repeated controls (9).

\section{Patient Visit}

Visitors should not be allowed, except for elderly and pediatric patients who cannot provide self-care. If the person / persons responsible for the care of the patient are required to enter the room of the patient with COVID-19 (+), they should be informed and supervised by a healthcare professional about putting on and removing PPE and hand hygiene practices before and after putting on PPE (9).

\section{Discharge in Inpatients}

1. Post-operative information should also include feedback from patients to their physician within the next 14 days in the presence of symptoms or signs of COVID-19. The paper-file transfer load should be reduced as much as possible. Active use of e-prescription system and e-report systems is important to reduce the risk of contamination. The patient should be discharged as soon as possible, if there is a drain, it should be emptied, and the patient should be educated about the care process such as simple dressings. In order to reduce the frequency of control, the patient should be given the care conditions in writing and the things to be done day by day should be explained $(9,19,27)$.

\section{Results}

In elective surgery planning, each institution should create its own roadmap with a multidisciplinary team, taking into account its own geographical location, patient variety and number, supply of consumables and their sustainability, and the role they play in the pandemic. Depending on the severity of the outbreak and the availability of resources, the risks and benefits of performing elective surgical procedures should be carefully considered during this period. During the "reopening" period of the COVID-19 pandemic, treatments should be applied for cases whose treatment was unfinished due to the epidemic or in cases where appropriate conditions are provided and recommendations made for patient/ physician safety are taken into account. It can be suggested that all physicians regarding the peak of COVID-19 cases, the return of implementation restrictions and social distancing measures, should create an emergency plan and make short-term patient planning considering the possibility of "re-closure".

Peer-review: Externally peer reviewed.

\section{Authorship Contributions}

Concept: Ö.D., D.D., Design: Ö.D., D.D., Data Collection or Processing: Ö.D., D.D., Analysis or Interpretation: Ö.D., D.D., Literature Search: Ö.D., D.D., Writing: Ö.D., D.D.

Conflict of Interest: No conflict of interest was declared by the authors.

Financial Disclosure: This work was supported by UpToDate.

\section{References}

1. Huang C, Wang Y, Li X, Ren L, Zhao J, Hu Y, et al. Clinical features of patients infected with 2019 novel coronavirus in Wuhan, China. Lancet 2020;395:497-506.

2. Guan WJ, Ni ZY, Hu Y, Liang WH, Ou CQ, He JX, et al. Clinical Characteristics of Coronavirus Disease 2019 in China. N Engl J Med 2020;382:1708-20.

3. Backer JA, Klinkenberg D, Wallinga J. Incubation period of 2019 novel coronavirus (2019-nCoV) infections among travellers from Wuhan, China, 20-28 January 2020. Euro Surveill 2020;25:2000062.

4. Assiri A, Al-Tawfiq JA, Al-Rabeeah AA, Al-Rabiah FA, Al-Hajjar S, Al-Barrak A. Epidemiological, demographic, and clinical characteristics of 47 cases of middle east respiratory syndrome coronavirus disease from Saudi Arabia: A descriptive study. Lancet Infect Dis 2013;13:752-61.

5. Chen N, Zhou M, Dong X, Qu J, Gong F, Han Y, et al Epidemiological and clinical characteristics of 99 cases of 2019 novel coronavirus pneumonia in Wuhan, China: A descriptive study. Lancet 2020;395:507-13.

6. ADA releases coronavirus handout for dentists based on CDC guidelines. American Dental Association 2020. Available from: https://www.ada.org/en/publications/ada-news/2020-archive/ february/ada-releases-coronavirus-handout-for-dentists-based-oncdc-guidelines.

7. Zimmermann M, Nkenke E. Approaches to the management of patients in oral and maxillofacial surgery during COVID-19 pandemic. J Craniomaxillofac Surg 2020;48:521-6.

8. Local resumption of elective surgery guidance. American College of Surgeon (17.04.2020). Available from: https:/www.facs.org/ covid-19/clinical-guidance/resuming-elective-surgery.

9. Interim Reopening Protocol for the OMS Office, COVID-19 Updates, American Association of Oral and Maxillofacial Surgeons, 2020.

10. CDC reminds clinicians to use standard precautions, recommends isolating patients with coronavirus symptoms. American Dental Association 2020. Available from: https://www.ada.org/en/ 
publications/ada-news/2020-archive/february/cdc-recommendsisolating-patients-with-coronavirus-symptoms.

11. T.C. Sağlık Bakanlığı. Covid-19 Temaslı değerlendirilmesi. Last Accessed Date: 21.04.2020. Available from: https://covid19bilgi. saglik.gov.tr/depo/enfeksiyon-kontorl-onlemleri/COVID19TemasliDegerlendirilmesi.pdf.

12. World Health Organization. Advice on the use of point-of-care immunodiagnostic tests for COVID-19 (4.8.2020). Available from: https://www.who.int/news-room/commentaries/detail/advice-onthe-use-of-point-of-care-immunodiagnostic-tests-for-covid-19.

13. ASA and APSF Joint Statement on Perioperative Testing for the COVID-19 Virus. Last Accessed Date: 28.04.2020.

14. Zhao J, Yuan Q, Wang H, Liu W, Liao X, Su Y, et al. Antibody responses to SARS-CoV-2 in patients with novel coronavirus disease 2019. Clin Infect Dis 2020;71:2027-34.

15. Okba NM, Muller MA, Li W, Wang C, GeurtsvanKessel CH, Corman VM, et al. SARS-CoV-2 specific antibody responses in COVID-19 patients. MedRxiv 2020.

16. T.C. Sağlık Bakanlığı. COVID-19 Pandemi döneminde alınacak önlemler. Available from: https://covid19bilgi.saglik.gov.tr/depo/ enfeksiyon-kontorl-onlemleri/COVID19-PandemiDonemindeAmel iyathanelerdeAlinacakEnfeksiyonKontrolOnlemleri.pdf

17. Infectious Diseases: 2019 Novel Coronavirus: American Dental Association; 2020. Available from: https://success.ada.org/en/ practice-management/

18. TC. Sağlık Bakanlığı. Covid-19 Dental işlemlerde Uyulması Gereken Enfeksiyon Kontrol Önlemleri. Last Accessed Date: 21.04.2020. Available from: https://covid19bilgi.saglik.gov.tr/depo/enfeksiyonkontorl-onlemleri/COVID19-DentalIslemlerdeUyulmasiGerekenEn feksiyonKontrolOnlemleri.pdf.
19. Chinese society of oral and maxillofacial surgery: Expert proposal for the management of oral maxillofacial surgery during the epidemic period of 2019-nCoV. Chin J Oral Maxillofac Surg 2020;18:97-9.

20. Marui VC, Souto MLS, Rovai ES, Romito GA, Chambrone L, Pannuti CM. Efficacy of preprocedural mouthrinses in the reduction of microorganisms in aerosol: A systematic review. J Am Dent Assoc 2019; 150:1015-26.

21. Peng X, Xu X, Li Y, Cheng L, Zhou X, Ren B. Transmission routes of 2019-nCoV and controls in dental practice. Int J Oral Sci 2020;12:9.

22. Aminian A, Safari S, Razeghian-Jahromi A, Ghorbani M, Delaney CP. COVID-19 outbreak and surgical practice: Unexpected fatality in perioperative period. Ann Surg 2020;272:27-9.

23. Lei S, Jiang F, Su W, Chen C, Chen J, Mei W, et al. Clinical characteristics and outcomes of patients undergoing surgeries during the incubation period of COVID-19 infection. EclinicalMedicine 2020;21:100331.

24. T.C. Sağlık Bakanlığı. COVID-19 Salgını Sırasında Uyulması Gereken Dental İşlemler Prosedürü. Last Accessed Date: 16.04.2020. Available from: https://covid19bilgi.saglik.gov.tr/depo/enfeksiyonkontorl-onlemleri/COVID19-SalginiSirasindaUyulmasiGerekenDe ntalIslemlerProseduru.pdf.

25. Day M. Covid-19: ibuprofen should not be used for managing symptoms, say doctors and scientists. BMJ 2020;368:1086.

26. Tan SHS, Hong CC, Saha S, Murphy D, Hui JH. Medications in COVID-19 Patients: Summarizing the Current Literature From an Orthopaedic Perspective. Int Orthop 2020;44:1599-603.

27. COVID-19 Salgın Sürecinde Ağız Diş ve Çene Cerrahisi Tedavi Kilavuz Önerisi, 2020. http://acbid.org/ACBID-COVID19-Kilavuz. pdf 